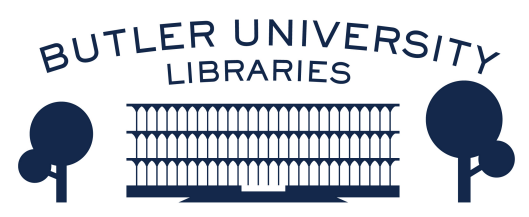

Journal of Hindu-Christian Studies

Volume 3

Article 5

January 1990

\title{
The Mystical Path of Total Abandonment to God in Jean-Pierre de Caussade and the "Bhagavad-Gita"
}

Robert L. Fastiggi

Follow this and additional works at: https://digitalcommons.butler.edu/jhcs

Part of the Religion Commons

\section{Recommended Citation}

Fastiggi, Robert L. (1990) "The Mystical Path of Total Abandonment to God in Jean-Pierre de Caussade and the "Bhagavad-Gita"," Journal of Hindu-Christian Studies: Vol. 3, Article 5.

Available at: https://doi.org/10.7825/2164-6279.1028

The Journal of Hindu-Christian Studies is a publication of the Society for Hindu-Christian Studies. The digital version is made available by Digital Commons @ Butler University. For questions about the Journal or the Society, please contact cbauman@butler.edu. For more information about Digital Commons @ Butler University, please contact digitalscholarship@butler.edu. 


\section{The Mystical Path of Total Abandonment to God in \\ Jean-Pierre de Caussade and the Bhagavad-Gita \\ Robert L. Fastiggi \\ St. Edward's University, Austin, Texas}

\section{Hindu Bhakti and Christian Devotion}

One of the creative tensions in Hinduism is the concept of God as Impersonal Absolute vs. the concept of God as Personal. In the Bhagavad-Gita (written c. 400200 B.C.), the concept of God as personal, loving and compassionate is emphasized. It is not surprising, therefore, that many scholars and spiritual writers have found in the Bhagavad-Gite a rich source of comparison with Christian spirituality. A definite similarity between the image of Krishna in the Bhagavad-Gita and the image of Christ in the New Testament has been observed. We need only compare the words of Krishna in the Gita with the words of Jesus in the Gospel of John. In the Hindu text, Krishna says: "but those who commune with Me in love's devotion (bhajanti bhakty $\bar{a}$ ) [abide] in Me, and I in them. (9:29)"' In the Christian text, Jesus says: "On that day you will realize that I am in my Father and you are in me and I in you (John 14:20)."

The recognition of a definite similarity between the path of bhakti proclaimed in the Gita and the path of love enjoined in the New Testament should not cause us to ignore the differences that exist between the two religious worldviews with which we are dealing. The Git $\bar{a}$ emerges out of a Hindu tradition which had already achieved speculative maturity on metaphysical and spiritual matters. The New Testament, though, emerges out of a Jewish worldview which was only beginning to incorporate certain elements of Greco-Roman philosophy. Thus, while it is possible to do a thorough comparison of the Bhagavad-Gita with parallel texts from the New Testament, I have chosen, instead, to concentrate on a later mystical text from the Christian tradition which attempts, like the Gitā, to show that complete love and abandonment to God is the highest path of spiritual liberation and union.

In the great spiritual classic, Abandonment to Divine Providence, we find a sustained discussion of the theme of spiritual devotion. The author of this classic is Jean-Pierre de Caussade (1675-1751), a seventeenth century Jesuit and spiritual guide. Abandonment to Divine Providence is actually a collection of various letters and lectures Caussade directed towards some French nuns of the Visitation Order. Caussade's spiritual instructions were saved and cherished by the Visitation nuns and eventually handed over to a Jesuit named Henri Ramière who edited and published them into a small book over one hundred years after the death of the author (1861).

Inspite of the differing religious and cultural contexts of these two writings, the spiritual paths enjoined by both Caussade and the Bhagavad-Gita are remarkably similar. Four definite movements of the spirit can be traced in each text: 1) a disciplined detachment from all selfish desires; 2) a complete surrender of the heart, mind and will to God; 3 ) the experience of peacefulness and beatitude once surrender to God takes place; and 4) a sense of divine omnipresence and glory. Although these spiritual movements are not always understood or presented in a sequential manner in either text, they still deserve individual attention.

Hindu-Christian Studies Bulletin 3 (1990) $13-20$ 


\section{Detachment from Desire}

The Bhagavad-Gitta was written within a few centuries of the beginnings of Buddhism in India. ${ }^{2}$ One of the central teachings of Buddhism is that suffering is the result of attachments and desires. The message of the Gitta can be understood as a response to the same problem perceived by Buddhism but with a different solution. Whereas Buddhism teaches the Noble Eightfold Path as the means of detachment from desires and cravings, the Gita offers detachment from selfish desires by means of attachment to the person of God. Thus, Krishna tells Arjuna: "Cast all your works on Me, your thoughts [withdrawn] in what pertains to self; have neither hope nor thought that 'This is mine': Cast off this fever! Fight!" (3:30).

The spiritual logic working here is simple but profound. Human beings are easy prey to all types of "vain hopes and selfish thoughts." So much the Buddhists have already said. However, the devotee offers up all of his or her works to God and rests the mind on God alone. Absolute surrender to God frees one from the bonds of attachment and leads to union with God. Speaking of the true devotee, Krishna says: "[His] self detached from contacts with the outside world, in [him] self he finds his joy, [his] self in Brahman integrated by spiritual exercise (brahmayoka yukt $\bar{a} t m \bar{a}$ ), he finds unfailing joy" (5:21). Such freedom results when attachment to God leads to detachment from the transient pleasures of life. Devotion to God, therefore, achieves the same goal for which the Buddhists so diligently labor: namely, detachment from selfish desires and the realization of bliss. The words of Krishna are so clear in this regard. Thus, he urges Arjuna: "Attach your mind to Me; engaging [still] in spiritual exercise put your trust in Me" (7:1). The person who puts total trust in the Blessed Lord experiences inner peace and "from attachment freed, steadfast and resolute, remains unchanged in failure and success..." (18:26).

Caussade's counsel regarding attachments to created things follows the same wisdom of both Buddhism and the Gitta. As he writes: "If we wish to enjoy an abundance of blessings we have only one thing to do: purify our hearts by emptying them of all desire for created things and surrender ourselves wholly to God." 3 Caussade, like the Git $\bar{a}$, sees absolute devotion and submission to God as the sure path to liberation and beatitude. His instruction on this matter is quite lucid:

How fortunate we are if we understand God's loving strictness and eagerly cooperate with it. We rise above all that passes away and repose in the unchanging and the infinite, and no longer put our trust in created things, but have dealings with them only when God wills it. God sees that we are empty of all our own desires and unable to make our own choice. We are dead and buried in complete indifference. When God in all his fullness comes and fills our hearts, he casts over all created things an annihilating shadow which blots out all their differences and variety. So these creatures lack all power to accomplish anything and we feel no attraction to them, for the majesty of God fills our hearts to overflowing. Dwelling in God, we are dead to all things, and all things are dead to us. (p. 75)

The spiritual logic of Caussade is quite direct: we must detach ourselves from created things in order that God may fill our hearts and minds with his all-pervasive 
presence. This state of detachment and abandonment, therefore, is the pure state of mind needed for the experience of God in each moment. As Caussade explains:

This annihilation of all creatures, and then their restoration to serve the designs of God, ensures that each moment God is both himself and all things to us. For at each moment our hearts are at peace in God and completely abandoned to all creation. Therefore each of these moments contain all things. (p. 75)

Both the Git $\bar{a}$ and Caussade demand a total detachment from selfish desires. As long as we are attached to the fruits of our actions, we remain in bondage. So much is clear in the Git $\bar{a}$ :

The integrated man, renouncing the fruit of works, gains an abiding peace: the man not integrated, whose works are prompted by desire, being attached to fruits is bound. (5:12).

In a similar way, Caussade tells how those who are abandoned to God experience serenity in any circumstance:

Whatever the world offers them is nothing. They judge all things by God's standards. If he takes from them their powers of thought and speech, their books, their food, their friends, their health, and even life itself, it means no more to them than if he did the exact opposite. They love all he does and find his activity always sanctifying (p. 61).

\section{Complete Surrender to God}

In the Bhagavad-Gita , there is a clear affirmation of love as the supreme path to the Godhead. Krishna tells Arjuna: "But by worship-of-love addressed to [Me], none other, Arjuna, can I be known and seen in such a form as I really am: [so can my lovers] enter into Me" (11:54). The effect of this love of God is salvation or liberation (moksha). The devotee is liberated from the bondage to selfish desire because his or her thoughts are fixed entirely upon God. There is a twofold movement in the process of salvation: the movement of the devotee towards God and the movement of God towards the devotee in grace. The two, though, work together. Krishna is willing to respond to any gesture of love on the part of the devotee. As we read: "Be it a leaf or a flower or fruit or water that a zealous soul may offer Me with love's devotion that do I [willingly] accept, for it was love that made the offering" (9:26). The true devotee ultimately dedicates all actions towards God as an expression of love. Krishna gives Arjuna the instruction: "Whatever you do, whatever you eat, whatever you offer in sacrifice or give away in alms, whatever penance you. may perform, offer it up to Me" (9:27). The result of this supreme devotion is harmony of soul and intimacy with God. Krishna says: "On Me your mind, on Me your loving-service, for Me your sacrifice, to me your prostrations; now that you have thus integrated self, your striving bent on $\mathrm{Me}$, to $\mathrm{Me}$, to $\mathrm{Me}$ you will [surely] come" (9:34).

The Git $\bar{a}$ also makes it clear that Krishna reaches out in compassion towards suffering humanity. In chapter 10, Krishna says: "Out of compassion for these same men [all] darkness born or ignorance I dispel with wisdom's shining lamp..." 
(10:11). In chapter 18, Krishna reveals: "Thinking on Me, you will surmount all dangers by my grace" (18:58). Krishna calls upon those who suffer to seek refuge in him: "Give up all things of law, turn to Me, your only refuge, [for] I will deliver you from all evils; have no care" (18:66). We see that the Gìtā makes clear the double movement of humanity reaching out towards God in devotion and God reaching out towards humanity in love. Krishna summarizes this point very well: "Bear Me in mind, love Me and worship Me, sacrifice, prostrate yourself to Me: so will you come to Me, I promise you truly, for you are dear to Me" (18:65).

Caussade likewise expresses the need for complete devotion to God. In a moment of self-revelation, Caussade tells God: "All I want to do is love you and devote myself to the duties of each moment, and so allow you to act on me as you wish" (p. 58). In many ways, the spirituality of Caussade is very simply stated. As he writes: "The essence of spirituality is contained in this phrase: "complete and utter abandonment to the will of God.' By that I mean we should never think of ourselves, but be continually occupied with loving and obeying him" (p. 73). Caussade believes the expression of this total abandonment to God is found in both active loyalty to the duties of our state of life and passive loyalty to whatever God wills for us. This attitude is summed up in this way: "We must be active in all that the present moment demands of us, but in everything else remain passive and abandoned and do nothing but peacefully await the promptings of God" (p. 79).

\section{The Experience of Peace and Beatitude}

The practice of bhakti and abandonment to God results in a deep sense of peacefulness and blessedness. It is the peace that the world cannot give. It is the peace of knowing that God loves us and wishes what is best for us. It is the peace that sees God in all things and all things in God. Krishna describes the peaceful person as the one who has "cast off [all] attachment to the fruit of works, ever content, on none dependent..." (4:20)." Whereas passions and desires cloud the mind and lead the soul into chaos, detachment brings forth a feeling of blessedness and joy. Krishna reveals the secret: "For upon this athlete of the spirit whose mind is stilled the highest joy descends: [all] passion laid to rest, free from [all] stain, Brahman he becomes (6:27)."

Caussade is moved by the same sense of joy. When we let go of our own will and our own selfishness, God becomes our constant source of joy. As we read: "We find all our joy in fulfilling God's pleasure - his happiness, his glory and the fact that he is our great and only delight. Once we have this foundation, all we need to do is to spend our lives rejoicing that God is God and being so wholly abandoned to his will that we are quite indifferent as to what use he makes of our activities. (p. 72)." This is a profound psychological as well as spiritual truth. Self-forgetfulness brings forth a sense of peace and a reduction of needless anxiety. Living in total abandonment to the will of God produces a freedom and protection from the oppressive "whips and scorns of time." Even the setbacks and annoyances of life can be peacefully endured by the person abandoned to God. As Caussade counsels:

My friends, you lack nothing. You would be very ashamed if you knew what the experiences you call setbacks, upheavals, disturbances, and 
tedious annoyances really are. You will realize that your complaints about them are nothing more nor less than blasphemies - though this never occurs to you. Nothing happens to you except by the will of God, and yet his beloved children curse it because they do not know it for what it is. (pp. 46-47).

\section{The Sense of Divine Omnipresence and Glory}

In both of these writings, there is a communicated a profound sense of divine omnipresence. In the Bhagavad-Gittä, Arjuna addresses Krishna in the most exalted language: "You are the Primal God, Primeval Person (ādidevah, purusah puranās), You of this universe the last prop-and-resting place, You are the knower and what is to be known, [You our] highest home, $\mathrm{O}$ You whose forms are infinite, by you the whole universe was spun" (11:38). Arjuna is blessed because Krishna tells him that his glory is not seen by all (7:25). What is it then that enables a person to see God? In part, it is due to an individual's willingness to concentrate the entire heart, mind and soul on God. In part, it is also due to the grace of revelation which provides glimpses of the celestial glory of the divine. Thus, in chapter 11, Krishna undergoes a transfiguration which enables Arjuna to see "the whole [wide] universe in One, converged, there in the body of the God of gods, yet divided in multiplicity." (11:13)

The Bhagavad Git $\bar{a}$ is filled with many powerful expressions of divine omnipresence and glory. Krishna says: "I am the Self established in the heart of all contingent beings," (10:20) "And what is the seed of all contingent beings, that too am I. No being is there, whether moving or unmoving, that exists or could exist apart from Me" (10:39). Krishna elsewhere reveals that "the splendour centered in the sun which bathes the whole world in light, [the splendour] in the moon and fire-know that it [all] is mine" (15:12). Krishna tells Arjuna that he penetrates the earth and sustains all beings with his strength (15:13), and that he transcends "the perishable" and is more exalted than "The Imperishable Itself" and thus he is extolled as "the Person [All] Sublime (purusottamah)" (15:18).

All of these expressions point to the mystery of divine transcendence and divine immanence. The Bhagavad-Git $\bar{a}$ is able to join these metaphysical concepts to the religious exercise of devotion, love and service to God. Although the knowledge of the universal spirit (Brahman) is present in the Gita , it is clearly superseded by loving devotion to Krishna as a personal God who transcends even the Imperishable which is "the highest Brahman" (8:3). Indeed, for the Gita , love is the lamp of knowledge. To love God is to know God. The words of Krishna express this with power and eloquence: "Do works for Me, make Me your highest goal, be loyal-inlove to Me, cut off all [other] attachments, have no hatred for any being at all: for all who do thus shall come to Me" (11:55). However, when one lives with complete devotion to God, the knowledge of God as the "Supreme Person" is also gained. This superior knowledge, by its very nature, gives rise to intimate love with God. Thus, knowledge unites with love, and love gives birth to knowledge. As Krishna reveals: "Whoever thus knows Me, unconfused, as the Person [All-] Sublime, knows all and [knowing all] communes with Me with all his being, all his love" (15:19). 


\section{Mystical Path of Total Abandonment}

Caussade echoes the same theme. Faith and total abandonment to the divine will are the keys that unlock the treasures of God's presence which are to be found everywhere.

Faith transforms the earth into paradise. By it our hearts are raised with joy of our nearness to heaven. Every moment reveals God to us. Faith is our light in this life.... Faith unlocks God's treasury. It is the key to all of the vastness of his wisdom. The hollowness of all created things is disclosed by faith, and it is by faith that God makes his presence plain. Faith tears aside the veil so that we can see everlasting truth. (p. 37).

The beauty of Caussade's spirituality is that it discloses God's presence in the midst of everyday experience, in "the sacrament of the present moment" (p. 24). Like the Gita a Caussade sees love as the true path to the knowledge of God. As he writes: For those who abandon themselves to it, God's love contains every good thing, and if you long for it with all your heart and soul it will be yours. All God asks for is love, and if you search for this kingdom where God alone rules, you can be quite sure you will find it" (p. 114). Abandonment to God is simultaneously an act of faith, hope and love. It is the sure path to the knowledge of God, and it is the sure path to salvation. Abandonment to God, as taught by Caussade, appears to be a Christian parallel of Hindu bhakti, the complete surrender of the soul to God in love.

\section{Conclusion}

In this age of scholarship and cross-cultural fertilization, it is sometimes important to be called back to the most fundamental aspirations of the human heart. Both the Bhagavad-Git $\bar{a}$ and Abandonment to Divine Providence lay open the simplicity and the beauty of the heart clinging to God in love. The realization that God is the source of all reality and the source of all life moves the human heart into a posture of dependence upon divine grace. Both the Git $\bar{a}$ and Caussade express this need for total surrender to God in love.

While the similarities between the two texts appear compelling, it is important to note a few possible differences. Caussade believes in God's omnipresence, but it is not entirely clear whether his Christian theism is the equivalent of the panentheism or "cosmotheism" of the Gita. Since the Gitta is such a rich and complex text, it is open to numerous interpretations within the various schools of Hindu thought. R. C. Zaehner believes that it is the school of Ramanuja known as visistā dvaita (qualified monism) which "probably comes nearest to the mind of the author of the Gita." 4 If this be true, then we would have to say that Caussade's sense of divine omnipresence differs from that of the Git $\bar{a}$ since he would always maintain an ontological difference between God and the created order. If there is a Christian thinker who approaches Ramanuja's sense of panentheism it would be Caussade's fellow Jesuit, Pierre Teilhard de Chardin (1881-1955), who might have been influenced by Caussade. ${ }^{5}$

Caussade's sense of the "sacrament of the present moment" is probably best interpreted as the recognition of the divine will or divine providence in all things. However, there are passages that do suggest a cosmic presence of the divine. For example, Caussade tells us that "God's activity runs through the universe. It wells up and around and penetrates every created being. Where they are, there it also is" (pp. 
25-26). No doubt, Teilhard could find nourishment for his concept of the "The Cosmic Christ" in passages like these along with his readings of certain passages of Paul and Greek Patristic sources.

Ultimately, it may be impossible to decide whether Caussade's sense of divine omnipresence is the same as that of the Gita . Historically, Christianity has tended to stress the radical difference between the Creator and creation while incorporating mystical traditions which sometimes move in the directions of panentheism and occasionally monism. Hinduism, on the other hand, has always had a stronger tendency towards monism, and panentheism emphasizes the difference between God and the phenomenal order.

Another possible difference between Caussade and the Gitta is in their understanding of the nature and purpose of detachment. The language of the Git $\bar{a}$ reflects a highly developed yogic system which has been nurtured and practiced for centuries within India. Caussade's language of detachment also reflects the historical tradition of Christian asceticism, especially in terms of the three stages of purgation, illumination and union. But is Hindu detachment the equivalent of Christian purgation? Certainly, both are intended as means for purifying the mind and the will of any obstacles which stand in the way of spiritual illumination. However, Hinduism has always had a more negative view of the worth of the phenomenal world and moksha has usually been understood as a release from the conditioned realm of phenomenal existence. Christianity, on the other hand, is a tradition with a greater affirmation of the importance of the temporal order and has always placed its hope in the renewal and transformation of creation rather than a release from it. To be sure, the history of Christian asceticism can give us many models of men and women who live in the world but are not of it. Yet, it is not certain whether the quietistic paradigm of Arjuna going into battle, detached from the concern of whom he might kill, is a model that a Christian could uncritically embrace. While Caussade speaks of the importance of fulfilling the duty of one's state in life, he also speaks about the importance of active loyalty to the will of God. For the Christian, therefore, the question must always be asked whether any given course of action is in harmony with the will of God.

In spite of these possible differences, the similarities between the two texts are noteworthy. Both of them deal with the question of how one can achieve peace and serenity in the midst of trials and struggles. The psychological root of pain is found by both authors in the selfish attachments to desires and material things. They both acknowledge God as a benevolent personality who has a deep and abiding love for the human person. For both of them, it is the awesome power and beauty of divine love that lifts the individual out of the conditioned realm of sin and pain and into the transcendent state of intimacy with God. This complete and utter abandonment of the soul to the will of God is understood as the royal path of Christian love and the sweet fragrance of Hindu bhakti.6. It is as if the author of the Gita and J.P. de Caussade are kindred souls who write centuries and continents apart in time and space, but somehow they come to cross paths in the spiritual geography of love and devotion to God. 
20 Mystical Path of Total Abandonment

Notes

1. The Bhagavad-Gitä: With a Commentary Based on the Original Sources by R. C. Zaehner (London: Oxford University Press, 1969), p. 77. Since all my citations from the Gita are taken from Zaehner's translation, the remaining citations will simply be indicated by chapter and verse.

2. Ibid., in Introduction, p. 7.

3. J. P. de Caussade, Abandonment to Divine Providence, trans. by John Beevers (New York, 1975), p. 68. All subsequent citations will be given by the page numbers in parentheses.

4. Zaehner, p. 8 .

5. See "Teilhard, Evil and Providence" by Thomas M. King S. J. in Teilhard Studies 21 (Spring/Summer, 1989).

6. It is worth noting that Zaehner sees a similarity between bhakti and the Christian love characterized by the "holy indifference" (sainte indifference) of St. François de Sales. Caussade certainly stands in this Salesian tradition, though he prefers the term abandonment over indifference. See Zaehner, p. 285. 